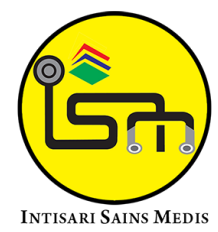

Published by Intisari Sains Medis

\section{Faktor risiko kejadian berat bayi lahir rendah di RSUP Sanglah, Denpasar, Bali, Indonesia}

\author{
I Gusti Ngurah Yuda Bagus Aryana ${ }^{1 *}$, Komang Ayu Kartika Sari², Putu Aryani ${ }^{2}$
}

1Program Studi Sarjana Kedokteran dan Profesi Dokter, Fakultas Kedokteran Universitas Udayana, Bali, Indonesia;

${ }^{2}$ Departemen Kesehatan Masyarakat dan Kedokteran Pencegahan, Fakultas Kedokteran Universitas Udayana, Bali, Indonesia.

\section{*Korespondensi:}

I Gusti Ngurah Yuda Bagus Aryana;

Program Studi Sarjana Kedokteran dan Profesi

Dokter, Fakultas Kedokteran Universitas Udayana,

Bali, Indonesiaemail:

dyudaaryana32@gmail.com

Diterima: 18-03-2021

Disetujui: 16-06-2021

Diterbitkan: 22-06-2021

\section{ABSTRACT}

Introduction: Maternal and child health has become a primary health focus in Indonesia and the maternal and child mortality rate in Indonesia is higher than those in South-East Asia countries. The incidence of Low Birth Weight (LBW) contributes to more than $50 \%$ of all neonatal mortality of all births in Indonesia. Therefore, identification of the risk factors that contributes to the incidence of $L B W$ is important.

Method: This retrospective case-control study involved 50 cases of LBW and 50 controls (baby with normal birth-weight), The data were analyzed using SPSS version 22.

Result: The results of multivariate analysis showed that

the factors significantly associated with LBW incidence were maternal blood pressure $(p=0.000)$, history of giving birth to $L B W$ babies $(p=0.000)$, and the mode of current labor $(p=0.034)$. The maternal age, maternal education level, maternal occupation, maternal anemia, parity, history of smoking, history of alcohol consumption, history of abortion, parity distance, and maternal BMI had no significant association ( $p>0.005)$. Conclusion: Thus, the incidence of LBW can be prevented through maternal blood control during the pregnancy. Careful history taking of past history of giving birth to LBW babies and the mode of delivery must be done to reduce the incidence of $L B W$.

Keywords: low birth weight, maternal risk, risk factors.

Cite This Article: Aryana, I.G.N.Y.B., Sari, K.A.K., Aryani, P. 2021. Faktor risiko kejadian berat bayi lahir rendah di RSUP Sanglah, Denpasar, Bali, Indonesia. Intisari Sains Medis 12(2): 427-432. D01: 10.15562/ism.v12i2.1006

\section{ABSTRAK}

Pendahuluan: Kesehatan ibu dan anak merupakan salah satu fokus utama kesehatan di Indonesia. Kasus kematian ibu dan anak di Indonesia lebih tinggi dibandingkan dengan negara-negara di Asia Tenggara. Kejadian bayi berat lahir rendah (BBLR) berkontribusi terhadap lebih dari 50\% total kematian neonatal di seluruh kelahiran di Indonesia. Oleh karena itu, identifikasi faktor-faktor risiko yang mendasari kejadian BBLR menjadi penting untuk dilakukan.

Metode: Penelitian kasus kontrol retrospektif ini melibatkan 50 kasus (BBLR) dan 50 kontrol (bayi lahir dengan berat badan normal. Data yang diperoleh kemudian dianalisis menggunakan perangkat SPSS versi 22.

Hasil: Hasil analisis multivariat didapatkan faktor-

faktor yang memiliki hubungan signifikan dengan kejadian BBLR adalah tekanan darah ibu $(p=0,000)$, riwayat melahirkan bayi $B B L R(p=0,000)$, dan tipe persalinan bayi saat ini $(p=0,034)$. Sebaliknya, faktor usia ibu, tingkat pendidikan ibu, pekerjaan ibu, anemia pada ibu, jumlah paritas, riwayat merokok, riwayat konsumsi alkohol, riwayat abortus, jarak paritas, dan IMT ibu tidak memiliki hubungan yang signifikan $(p>0,005)$.

Simpulan: Pencegahan kejadian BBLR dapat dilakukan dengan mengontrol tekanan darah ibu selama kehamilan. Penggalian riwayat melahirkan bayi BBLR sebelumnya dan pemilihan metode persalinan juga harus dilakukan dengan seksama untuk mengurangi kejadian BBLR.

Kata kunci: berat badan lahir rendah, faktor risiko, risiko maternal..

Sitasi Artikel ini: Aryana, I.G.N.Y.B., Sari, K.A.K., Aryani, P. 2021. Faktor risiko kejadian berat bayi lahir rendah di RSUP Sanglah, Denpasar, Bali, Indonesia. Intisari Sains Medis 12(2): 427-432. D0I: 10.15562/ism.v12i2.1006

\section{PENDAHULUAN}

Angka kematian ibu dan anak masih menjadi perhatian utama di Indonesia dengan kasus yang cukup tinggi, khususnya untuk mencapai target Millenium Development Goals (MDGs). Angka kematian ibu (AKI) di Indonesia sendiri sebesar 307 per 100.000 kelahiran hidup, sedangkan angka kematian bayi (AKB) mencapai 35 per 1.000 kelahiran hidup. ${ }^{1}$ Kasus kematian ibu dan anak di Indonesia tergolong tinggi, bahkan 
lebih tinggi jika dibandingkan dengan jumlah kasus di negara-negara ASEAN. Hingga saat ini Indonesia belum mampu mencapai target MDGs. Berbagai penyebab kematian bayi telah dilaporkan oleh Riset Kesehatan Dasar di tahun 2007, seperti sepsis (20,5\%), kelainan kongenital $(18,1 \%)$, pneumonia $(15,4 \%)$, prematuritas dan bayi dengan berat badan lahir rendah (BBLR) (12,8\%). Dari berbagai penyebab tersebut, BBLR sendiri berkontribusi terhadap lebih dari $50 \%$ total kematian neonatal di seluruh kelahiran. ${ }^{2}$

World Health Organization (WHO) mengklasifikasikan BBLR sebagai kondisi berat badan lahir bayi kurang dari 2500 gram yang diukur dalam satu jam setelah kelahiran bayi. Selanjutnya, BBLR dikategorikan menjadi bayi dengan berat badan lahir sangat rendah (BBLSR $<1500$ gram), dan bayi dengan berat badan lahir sangat amat rendah (BBLSAR $<1000$ gram). ${ }^{1}$ Secara global, kejadian BBLR diestimasikan mencapai $15-20 \%$ dari keseluruhan persentase kelahiran atau dapat dikatakan bahwa $>20$ juta bayi baru lahir akan mengalami BBLR. ${ }^{1}$ Sekitar 90\% kasus BBLR terjadi di negara dengan pendapatan rendah dan BBLR sendiri berasosiasi erat dengan faktor - faktor yang ditemukan pada negara berkembang, seperti faktor sosioekonomi. ${ }^{3}$

Selain menjadi indikator status kesehatan, status gizi, dan status sosioekonomi suatu negara, kejadian BBLR dapat mempengaruhi aspek kognitif dan perkembangan perilaku dalam tahun pertama kehidupan, Oleh sebab itu, identifikasi faktor yang mempengaruhi kejadian BBLR sangatlah penting. ${ }^{4}$ Faktorfaktor yang telah dilaporkan berbagai studi dapat berasosiasi dan memengaruhi kejadian BBLR antara lain adalah kadar hemoglobin ibu, usia ibu saat melahirkan, tipe persalinan, tingkat pendidikan ibu, pekerjaan/mata pencaharian ibu, jumlah paritas, alamat tinggal ibu, riwayat merokok, riwayat konsumsi alkohol, riwayat abortus, tekanan darah ibu, riwayat penyakit sistemik pada ibu, usia kandungan saat kelahiran bayi, berat bayi saat lahir, indeks massa tubuh ibu sebelum melahirkan, lingkar lengan atas ibu, usia kehamilan saat persalinan, tinggi badan, dan berat badan ibu. ${ }^{5}$ Namun, hingga saat ini belum banyak penelitian yang memberikan data ilmiah mengenai faktor-faktor atau determinan yang mendasari kejadian BBLR. Oleh karena itu, penelitian yang secara khusus berfokus pada identifikasi faktor yang memiliki asosiasi positif atau negatif signifikan secara statistik terhadap kecenderungan terjadinya BBLR ini dilakukan. Penelitian ini dilakukan di RSUP Sanglah sebagai tempat pelayanan kesehatan tersier di Bali.

\section{METODE}

\section{Rancangan penelitian dan populasi}

Penelitian ini adalah penelitian observasional dengan desain studi case-control menggunakan pendekatan retropektif. Penelitian dilakukan di Instalasi Rekam Medis RSUP Sanglah Denpasar, Bali pada periode April November 2020. Pengambilan sampel menggunakan consecutive sampling sesuai kriteria penelitian. Seluruh bayi yang lahir hidup dengan berat badan lahir normal dan bayi yang terdiagnosis dengan berat lahir rendah $(<2.500$ gram $)$ di RSUP Sanglah Denpasar pada tahun 2019 2020 yang teregister di Instalasi Rekam Medis Sanglah pada periode penelitian diambil sebagai subjek penelitian. Bayi dengan berat badan lahir normal menjadi kelompok kontrol, sedangkan bayi dengan berat lahir rendah menjadi sebagai kelompok kasus. Bayi yang memiliki kelainan kongenital, lahir mati pada periode 2019-2020, dan memiliki data rekam medis yang tidak lengkap dieksklusi dari penelitian.

Faktor risiko terhadap BBLR yang diteliti pada penelitian ini adalah usia ibu, tingkat Pendidikan ibu, pekerjaan ibu, jarak paritas, kadar hemoglobin, tiper persalinan, jumlah paritas, riwayat merokok, riwayat konsumsi alkohol, usia kehamilan, riwayat abortus, tekanan darah, dan indeks massa tubuh (IMT).

\section{Analisis data}

Data yang diperoleh dianalisis menggunakan program SPSS versi 22. Analisis univariat dilakukan untuk mengetahui distribusi dan karakteristik variable sampel penelitian. Analisis bivariat digunakan untnuk mencari hubungan tiap variable faktor risiko dengan BBLR. Apabila hasil yang ditemukan signifikan, dilanjutkan analisis odd ratio (OR) untuk memperoleh nilai risiko. Analisis bivariat yang digunakan dalam penelitian ini adalah uji Pearson Chi-Square, Fisher Exact, dan Kruskal wallis. Uji Fisher's exact digunakan dalam analisis jumlah paritas karena tidak memenuhi kriteria chi-square (terdapat 1 sel dengan jumlah sampel <5). Analisis Multivariat berupa uji regresi multinominal dilakukan untuk mengetahui faktor risiko manakah yang paling berpengaruh terhadap kejadian BBLR dan mengontrol variable faktor risiko satu dengan yang lain agar tidak menjadi perancu dalam hubungan independent antar masing - masing faktor risiko dan kejadian BBLR yang diteliti.

Penelitian ini telah mendapatkan izin epenlitian dari institusi terkait dan kerahasiaan pasien dijaga dengan tidak mencantumkan identitas dan hal-hal yang bersifat privasi pada hasil penelitian.

\section{HASIL}

Penelitian ini melibatkan 100 bayi baru lahir yang kemudian dibagi menjadi dua kelompok, yakni kelompok kasus (bayi BBLR) sebanyak 50 bayi dan kelompok kontrol (bayi dengan berat badan lahir normal) sebanyak 50 bayi. Dari total 100 sampel yang terlibat, usia ibu termuda yang melahirkan bayi dengan berat lahir rendah adalah 16 tahun dan paling tua adalah 41 tahun. Sementara itu usia ibu termuda yang melahirkan bayi dengan berat badan normal adalah 17 tahun dan usia ibu tertua yaitu 41 tahun. Sebanyak $20 \%$ dari keseluruhan subjek dalam studi ini merupakan ibu yang tergolong dalam kelompok usia berisiko yaitu dengan usia kurang dari 20 tahun atau lebih dari 35 tahun. Sebagian besar sampel ibu memiliki tingkat pendidikan tamatan SMA (80\%). Hanya sebagian kecil ibu dari total sampel memiliki riwayat hipertensi (19\%). Sementara itu $40 \%$ dari total sampel merupakan ibu dengan riwayat anemia dengan rincian $26 \%$ memiliki anemia derajat sedang, diikuti dengan $12 \%$ memiliki anemia ringan dan hanya $2 \%$ memiliki anemia berat. $5 \%$ dari total sampel termasuk berisiko berdasarkan jumlah anak yang dimiliki sebelumnya, dimana mereka yang berisiko memiliki 4-5 anak (data tidak diperlihatkan). Sebanyak 13\% memiliki riwayat melahirkan bayi dengan BBLR sebelumnya. Tidak ada 
ibu yang memiliki riwayat merokok dan konsumsi alkohol. Sebanyak 17\% sampel ibu pernah mengalami abortus

sebelumnya dan hanya 19\% dari total sampel memiliki risiko dalam hal jarak melahirkan anak saat ini dengan kelahiran

Tabel 1. Distribusi Karakteristik Sampel dan Hasil Analisis Bivariat Faktor Risiko Kejadian BBLR

\begin{tabular}{|c|c|c|c|c|}
\hline \multirow{2}{*}{ Variabel } & \multicolumn{2}{|c|}{ Jumlah Sampel (\%) } & \multirow{2}{*}{$\begin{array}{c}\text { Nilai } \\
\text { OR }\end{array}$} & \multirow{2}{*}{ Nilai $p$} \\
\hline & BBLR & Normal & & \\
\hline Usia Ibu & 16-41 tahun & 17-41 tahun & & \\
\hline $\begin{array}{l}\text { Berisiko } \\
\text { Tidak berisiko }\end{array}$ & $\begin{array}{l}12(12 \%) \\
38(38 \%)\end{array}$ & $\begin{array}{c}8(8 \%) \\
42(42 \%)\end{array}$ & - & 0,317 \\
\hline \multicolumn{5}{|l|}{ Tingkat Pendidikan Ibu } \\
\hline $\begin{array}{l}\text { Tamat SD } \\
\text { Tamat SMP } \\
\text { Tamat SMA } \\
\text { Tamat S1/D4/D3/D2/D1 }\end{array}$ & $\begin{array}{c}1(1 \%) \\
2(2 \%) \\
44(44 \%) \\
3(3 \%)\end{array}$ & $\begin{array}{c}2(2 \%) \\
4(4 \%) \\
36(36 \%) \\
8(8 \%)\end{array}$ & - & 0,258 \\
\hline \multicolumn{5}{|l|}{ Pekerjaan Ibu } \\
\hline $\begin{array}{l}\text { Ibu Rumah Tangga } \\
\text { Pelajar } \\
\text { Petani/Nelayan } \\
\text { Wiraswasta } \\
\text { Pegawai (Swasta ataupun PNS) } \\
\text { Manajerial (Swasta ataupun PNS) }\end{array}$ & $\begin{aligned} 21 & (21 \%) \\
2 & (2 \%) \\
1 & (1 \%) \\
7 & (7 \%) \\
18 & (18 \%) \\
1 & (1 \%)\end{aligned}$ & $\begin{aligned} 21 & (21 \%) \\
1 & (1 \%) \\
1 & (1 \%) \\
7 & (7 \%) \\
20 & (20 \%) \\
0 & (0 \%)\end{aligned}$ & - & 0,923 \\
\hline \multicolumn{5}{|l|}{ Tekanan Darah Ibu } \\
\hline $\begin{array}{l}\text { Hipertensi } \\
\text { Normal }\end{array}$ & $\begin{array}{l}17(17 \%) \\
33(33 \%)\end{array}$ & $\begin{array}{c}2(2 \%) \\
48(48 \%)\end{array}$ & 18,03 & $0,002^{*}$ \\
\hline \multicolumn{5}{|l|}{ Status Anemia Ibu } \\
\hline $\begin{array}{l}\text { Anemia Ringan } \\
\text { Anemia Sedang } \\
\text { Anemia Berat } \\
\text { Tidak Anemia }\end{array}$ & $\begin{array}{c}5(5 \%) \\
14(14 \%) \\
1(1 \%) \\
30(30 \%)\end{array}$ & $\begin{aligned} 7 & (7 \%) \\
12 & (12 \%) \\
1 & (1 \%) \\
30 & (30 \%)\end{aligned}$ & - & 0,923 \\
\hline \multicolumn{5}{|l|}{ Risiko Jumlah Paritas } \\
\hline $\begin{array}{l}\text { Berisiko } \\
\text { Tidak Berisiko }\end{array}$ & $\begin{array}{c}4(4 \%) \\
46(46 \%)\end{array}$ & $\begin{array}{c}1(1 \%) \\
49(49 \%)\end{array}$ & - & 0,362 \\
\hline \multicolumn{5}{|l|}{ Riwayat Melahirkan Bayi BBLR } \\
\hline $\begin{array}{l}\text { Ya } \\
\text { Tidak }\end{array}$ & $\begin{array}{l}13(13 \%) \\
37(37 \%)\end{array}$ & $\begin{array}{c}0(0 \%) \\
50(50 \%)\end{array}$ & 1,02 & $0,000^{*}$ \\
\hline \multicolumn{5}{|l|}{ Riwayat Merokok } \\
\hline $\begin{array}{l}\text { Ya } \\
\text { Tidak }\end{array}$ & $\begin{array}{c}0(0 \%) \\
50(50 \%)\end{array}$ & $\begin{array}{c}0(0 \%) \\
50(50 \%)\end{array}$ & - & - \\
\hline \multicolumn{5}{|l|}{ Riwayat Konsumsi Alkohol } \\
\hline $\begin{array}{l}\text { Ya } \\
\text { Tidak }\end{array}$ & $\begin{array}{c}0(0 \%) \\
50(50 \%)\end{array}$ & $\begin{array}{c}0(0 \%) \\
50(50 \%)\end{array}$ & - & - \\
\hline \multicolumn{5}{|l|}{ Riwayat Abortus } \\
\hline $\begin{array}{l}\text { Ya } \\
\text { Tidak }\end{array}$ & $\begin{array}{c}7(7 \%) \\
43(43 \%)\end{array}$ & $\begin{array}{l}10(10 \%) \\
40(40 \%)\end{array}$ & - & 0,424 \\
\hline \multicolumn{5}{|l|}{ Risiko Jarak Paritas } \\
\hline $\begin{array}{l}\text { Berisiko } \\
\text { Tidak Berisiko }\end{array}$ & $\begin{array}{l}12(12 \%) \\
38(38 \%)\end{array}$ & $\begin{array}{c}7(7 \%) \\
43(43 \%)\end{array}$ & - & 0,202 \\
\hline \multicolumn{5}{|l|}{ IMT Ibu } \\
\hline $\begin{array}{l}\text { Berat Badan Kurang } \\
\text { Normal } \\
\text { Berat Badan Berlebih } \\
\text { Obesitas }\end{array}$ & $\begin{array}{c}3(3 \%) \\
32(32 \%) \\
12(12 \%) \\
3(3 \%)\end{array}$ & $\begin{array}{c}1(1 \%) \\
37(37 \%) \\
12(12 \%) \\
0(0 \%)\end{array}$ & - & 0,229 \\
\hline
\end{tabular}

${ }^{*}$ signifikan secara statistik $(\mathrm{p}<0,01)$ anak sebelumnya. Terakhir, sebagian besar sampel ibu memiliki IMT normal (69\%) diikuti dengan berat badan berlebih sebanyak $24 \%$, berat badan kurang $4 \%$ dan ibu dengan obesitas sebanyak 3\% (Tabel 1).

Setiap variabel kemudian dilakukan analisis bivariat untuk mengetahui pegnaruhnya terhadap kejadian BBLR. Khusus untuk variabel riwayat merokok dan konsumsi alkohol yang tidak dapat dianalisis lebih lanjut karena tidak ada sampel pada kedua kelompok. Distribusi variabel penelitian berdasarkan kelompk kasus dan kontrol serta hasil analisis bivariat disajikan pada Tabel 1. Hanya variabel tekanan darah ibu dan riwayat melahirkan bayi BBLR yang terbukti signifikan secara statistik $(p<0,01)$, sedangkan variabel lainnya yakni usia ibu, tingkat pendidikan ibu, pekerjaan ibu, status anemia ibu, risiko jumlah paritas, riwayat abortus, risiko jarak paritas, dan IMT ibu ditemukan tidak signifikan secara statistik ( $\mathrm{p}>0,01)$. Terlihat bahwa ibu yang memiliki riwayat hipertensi memiliki risiko 18 kali lebih tinggi $(\mathrm{OR}=18,03$; $\mathrm{p}<0,01)$ untuk melahirkan BBLR dibandingkan dengan ibu tanpa riwayat hipertensi. Hal ini juga berlaku untuk faktor risiko riwayat melahirkan bayi BBLR sebelumnya, dimana dalam studi ini para ibu yang pernah melahirkan bayi BBLR berisiko melahirkan BBLR kembali sebanyak 1,02 kali dibandingkan dengan mereka yang tidak pernah sebelumnya.

Variabel yang ditemukan bermakna secara statistik yakni tekanan darah ibu dan riwayat melahirkan dilakukan analisis multivariat yang disajikan pada Tabel 2. Berdasarkan hasil analisis ditemukan bahwa tekanan darah dan riwayat melahirkan bayi BBLR memang berhubungan secara signifikan dengan kejadian BBLR dengan masing-masing nilai $\mathrm{p}$ yang sama $(\mathrm{p}=0,000)$. Dengan peningkatan satu unit tekanan darah ibu, maka akan mengalikan risiko BBLR sebanyak 11,52. Begitu pula dengan peningkatan satu unit riwayat melahirkan BBLR akan mengalikan risiko BBLR selanjutnya sebanyak 1,03. Dari hasil temuan ini maka dapat disimpulkan bahwa dari seluruh dua belas faktor risiko yang diteliti, terdapat dua faktor risiko yang berhubungan signifikan dengan 
Tabel 2. Hasil Analisis Multivariat Faktor Risiko Kejadian BBLR

\begin{tabular}{|c|c|c|c|c|}
\hline Variabel & & Adjusted OR & Nilai p & IK95\% \\
\hline Konstanta BBLR & 22,283 & & & \\
\hline Tekanan Darah Ibu & & 11,520 & $0,000^{* *}$ & $0,009-0,351$ \\
\hline Riwayat Melahirkan BBLR & & 1,027 & $0,000^{* *}$ & $0,005-0,426$ \\
\hline
\end{tabular}

${ }^{\star}$ signifikan secara statistik $(\mathrm{p}<0,01)$

kejadian BBLR dalam penelitian ini.

\section{PEMBAHASAN}

BBLR merupakan masalah kesehatan masyarakat yang penting, karena berhubungan dengan morbiditas dan mortalitas neonatus. Berat badan lahir bergantung pada interaksi yang rumit antara genotipe ibu dan janin, fungsi plasenta, serta pengaruh faktor maternal terhadap regulator epigenetik aktivitas gen. ${ }^{6}$ Namun terdapat faktor ekstrinsik lain terkait dengan berat badan lahir yang dapat memengaruhi luaran kesehatan neonatus. ${ }^{7}$ Faktor-faktor ekstrinsik yang umumnya dapat dimodifikasi tersebut selayaknya menjadi fokus dalam penelitian untuk mengupayakan pemenuhan target kesehatan negara-negara di dunia. ${ }^{8}$

Hanya sebagian kecil ibu (20\%) yang termasuk dalam kelompok usia berisiko dalam penelitian ini. Proporsi ini tepat mewakili hasil studi epidemiologi di Amerika Serikat yang melaporkan bahwa sebanyak $5 \%$ persalinan berasal dari ibu yang berusia kurang dari 20 tahun dan hampir $18 \%$ persalinan berasal dari ibu yang berusia 35 tahun atau lebih. ${ }^{9}$ Demografi yang serupa dapat diamati terlepas dari perbedaan minor pada batas bawah kelompok usia lanjut yang berisiko.

Distribusi tingkat pendidikan ibu pada penelitian ini menunjukkan bahwa sebagian besar ibu (80\%) telah memenuhi program wajib belajar 12 tahun yang ditetapkan dalam program pemerintah yang diatur dalam Undang-Undang Republik Indonesia Nomor 20 Tahun 2003. Disparitas status sosioekonomi ibu memiliki pengaruh yang besar terhadap kesehatan anak, terutama pada negara dengan pendapatan rendah hingga menengah. Ibu dengan tingkat pendidikan yang tinggi memiliki risiko yang lebih rendah untuk mengalami persalinan preterm, BBLR, kecil untuk usia kehamilan, dan distres napas pada bayi. ${ }^{10}$ Penurunan risiko ini kemungkinan disebabkan oleh perbedaan dalam kecenderungan orang tua dalam memprioritaskan kesehatan anak. ${ }^{11}$

Mayoritas ibu (42\%) yang terlibat dalam penelitian ini berfokus dalam perannya sebagai ibu rumah tangga. Terdapat inkonsistensi pada hubungan status pekerjaan ibu dengan luaran pada kesehatan anak. Studi berbasis populasi di Eropa menunjukkan bahwa ibu yang bekerja pada sebagian besar sektor pekerjaan memiliki risiko yang lebih rendah untuk mengalami persalinan preterm. ${ }^{12}$ Namun hasil penelitian terdahulu didominasi oleh dampak buruk yang disebabkan oleh pekerjaan ibu, seperti persalinan preterm dan bayi kecil untuk usia kehamilan, serta BBLR, oligohidramnion, dan abrupsio plasenta. ${ }^{13}$ Faktor-faktor yang berkontribusi dalam luaran yang buruk pada lingkungan pekerjaan meliputi aktivitas mengangkat beban berat, lingkungan yang lembab, kontak dengan deterjen, dan harus berada dalam posisi berdiri atau duduk dalam jangka waktu yang lama. ${ }^{11,13}$

Pada penelitian ini ditemukan bahwa hipertensi dalam kehamilan merupakan faktor risiko kejadian BBLR yang signifikan $(p<0,01)$. Penelitian-penelitian serupa sebelumnya menunjukan hubungan yang tidak konsisten. Hasil yang sejalan dilaporkan pada penelitian oleh Adane dan Dachew pada tahun 2018 (odds ratio [OR] 6,5; 95\% Interval Kepercayaan [IK] 3,06-14,0) dan penelitian oleh Valadbeigi dkk pada tahun 2019 (OR 1,91, 95\%IK 1,44-2,54) yang menemukan hipertensi dalam kehamilan sebagai faktor yang berkaitan dengan BBLR. Tinjauan sistematik dan meta-analisis oleh Getaneh dkk. ${ }^{14}$ kemudian mengonfirmasi asosiasi tersebut (pooled OR 3,89; 95\%IK 2,66$5,69)$.

Terdapat perkembangan bukti ilmiah terkini mengenai hubungan riwayat BBLR maternal dengan terjadinya hipertensi dalam kehamilan., ${ }^{215}$ Kemungkinan akan adanya hubungan bidireksional dapat membawa implikasi yang besar yang membutuhkan perhatian lebih untuk memutus lingkaran setan tersebut.

Penelitian ini mendapatkan hasil bahwa riwayat melahirkan BBLR merupakan salah satu faktor risiko yang berhubungan dengan kejadian BBLR ( $p$ value $=0.000$ ). Beberapa studi sebelumnya menunjukkan bahwa prematur dan BBLR cenderung berulang dalam keluarga. Akan terjadi peningkatan risiko kelahiran prematur dan BBLR pada wanita dengan riwayat melahirkan prematur maupun BBLR. ${ }^{16}$ Wanita dengan riwayat BBLR sebelumnya merupakan potential carriers untuk risiko rekurensi BBLR yang lebih tinggi pada kehamilan berikutnya dibandingkan dengan wanita yang memiliki bayi dengan berat lahir normal sebelumnya. ${ }^{17}$ Menurut salah satu studi cohort, bahwa ibu dengan riwayat melahirkan BBLR sebelumnya memiliki risiko 1,5 kali lebih tinggi untuk melahirkan bayi BBLR pada kehamilan selanjutnya. Adanya rekurensi BBLR ini juga dikaitkan dengan tingginya jumlah paritas, kondisi sosial ekonomi yang lebih rendah, riwayat ibu melahirkan prematur, kualitas perawatan antenatal yang rendah, dan kenaikan berat badan ibu yang tidak adekuat selama kehamilan. ${ }^{18}$ Studi lainnya menunjukkan bahwa rekurensi BBLR berkaitan dengan ibu yang merokok, jarak paritas yang lebih pendek dan usia ibu lebih dari 30 tahun. ${ }^{19}$

Studi oleh Sclowitz dkk. ${ }^{20}$ menemukan bahwa ibu dengan riwayat melahirkan BBLR sebelumnya memiliki risiko empat kali lipat lebih tinggi untuk mengalami rekurensi BBLR. Studi oleh Mvunta dkk. ${ }^{17}$ menunjukkan bahwa riwayat melahirkan BBLR pada kehamilan pertama akan meningkatkan risiko BBLR padakehamilan berikutnya $(R R=5,08$, IK95\%= 4,01-6,45). Penelitian lainnya menunjukkan bahwa ibu dengan riwayat melahirkan BBLR memiliki risiko 3.74 kali lebih tinggi untuk mengalami rekurensi melahirkan BBLR (Adjusted OR=3,74; IK95\%=1.03-13.58; $\mathrm{p}=0.045){ }^{21}$ Rekurensi BBLR disebutkan tidak terkait dengan ketepatan ibu dalam melakukan kunjungan ANC, namun berkaitan dengan kenaikan berat badan yang tidak adekuat selama kehamilan. 
Kenaikan berat badan di atas $10 \mathrm{~kg}$ selama kehamilan dapat menjadi faktor protektif terhadap rekurensi BBLR, dan semakin tinggi kenaikan berat badan pada kehamilan selanjutnya akan menurunkan risiko rekurensi BBLR. ${ }^{20}$

Salah satu global survey dengan populasi penelitian pada 23 negara berkembang di benua Asia, Afrika dan Amerika menunjukkan bahwa BBLR dikaitkan dengan kematian perinatal, dan berhubungan dengan peningkatan risiko BBLR pada kehamilan berikutnya. Berat badan lahir rendah dapat menggambarkan kondisi janin yang kurang optimal dalam kandungan dan/atau short pregnancies. Bahkan pada wanita dengan anak pertama yang memiliki berat lahir rendah dan bertahan hidup selama 28 hari pascapartum, terdapat hubungan yang kuat antara BBLR pada kehamilan pertama dan risiko lahir mati pada kehamilan berikutnya. Kondisi ini menunjukkan bahwa penyebab kematian perinatal sangat berhubungan dengan BBLR. ${ }^{22}$

Rekurensi BBLR dapat pula disebabkan oleh adanya polimorfisme methylenetetrahydrofolate reductase (MTHFR) C677T genotip TT pada ras Asia dan Kaukasian. Methylenetetrahydrofolate reductase (MTHFR) memiliki peran penting dalam metabolisme folat yaitu mengubah 5,10-methylenetetrahydrofolate menjadi 5-methyltetrahydrofolate dan berperan dalam proses enzimatik penting dalam remetilasi homosistein (Hcy) menjadi metionin..$^{23}$ Singkatnya, MTHFR menggunakan folat untuk metabolisme sehingga akan terjadi peningkatan konsentrasi plasma homosistein ketika aktivitas enzim berkurang. Kondisi tersebut akan menyebabkan stres oksidatif, penyempitan arteriol, kerusakan endotel, dan trombosis plasenta. ${ }^{24}$ Selanjutnya akan terjadi gangguan aliran darah dan perubahan prothrombotik pada dinding pembuluh darah, invasi trofoblas yang tidak adekuat ke dalam pembuluh darah uterus, dan hipoperfusi plasenta yang kemudian menyebabkan janin kekurangan nutrisi sehingga dapat menimbulkan perburukan kondisi janin seperti BBLR dan kelahiran preterm. Kondisi tersebut menunjukkan bahwa kesehatan janin tidak hanya bergantung pada invasi trofoblas ke dalam pembuluh darah uterus, tetapi juga bergantung pada sirkulasi uteroplasenta yang adekuat pada ibu. ${ }^{25}$

Faktor-faktor sosiodemografi maternal berupa usia, tingkat pendidikan, dan pekerjaan tidak memiliki hubungan yang signifikan dengan BBLR pada penelitian ini. Hal ini terkait dengan distribusi sampel dalam kaitannya dengan luaran berat badan lahir normal atau rendah. Jumlah sampel berdasarkan masingmasing luaran tersebut relatif seimbang sehingga tidak menghasilkan hubungan yang signifikan secara statistik.

Hubungan antara anemia maternal dengan BBLR telah diamati pada penelitian-penelitian sebelumnya. ${ }^{26}$ Akan tetapi, penelitian-penelitian tersebut mendapatkan adanya heterogenitas yang disebabkan oleh perbedaan dalam besar sampel, metodologi penelitian, serta tingkat status ekonomi negara dari sampel penelitian. Perbedaan dalam aspek-aspek tersebut dapat membantu menjelaskan hubungan yang tidak signifikan dalam penelitian ini. Selain itu, studi lain menyatakan bahwa risiko dapat bervariasi berdasarkan trimester kehamilan, dimana variabel trimester kehamilan saat terjadinya anemia tidak ditelaah lebih lanjut pada penelitian ini. ${ }^{27}$

Jumlah paritas dilaporkan sebagai faktor risiko BBLR dalam penelitian terdahulu. $^{28}$ Namun pada penelitian tersebut paritas dikategorikan sebagai primipara dan multipara, sedangkan pada penelitian ini jumlah paritas dikatakan berisiko bila bernilai empat ke atas mengacu pada definisi grande multi. ${ }^{28}$ Hasil penelitian ini sejalan dengan penelitian oleh Syahraeni dan Achmad (2013) dengan proporsi ibu dengan paritas tinggi $(4,5 \%)$ serupa dengan penelitian ini $(5 \%)$.

Tinjauan sistematik dan meta-analisis sebelumnya menemukan hubungan antara status ibu sebagai perokok aktif dengan kejadian BBLR, namun tidak pada hubungan konsumsi alkohol dengan kejadian BBLR. Pada penelitian ini hubungan tersebut tidak dapat dianalisis lebih lanjut karena tidak ada sampel yang memiliki faktor risiko tersebut. ${ }^{29}$ Penting untuk diingat bahwa data terkait variabel perilaku merokok dan konsumsi alkohol bersifat subjektif dan berkaitan dengan keterbukaan individu. ${ }^{30}$

\section{SIMPULAN}

Tekanan darah ibu dan riwayat melahirkan bayi BBLR sebelumnya terbukti merupakan faktor risiko kejadian BBLR pada penelitian ini. Ibu dengan hipertensi memiliki risiko 11,52 kali lebih tinggi melahirkan bayi BBLR dan ibu dengan riwayat melahirkan bayi BBLR sebelumnya memiliki risiko 1,03 kali lebih tinggi melahirkan bayi BBLR. Indeks massa tubuh, usia ibu hamil, tingkat pendidikan, pekerjaan ibu hamil, tingkat pendidikan, pekerjaan ibu hamil, jarak paritas, kadar haemoglobin, jumlah parita, riwayat merokok, usia kehamilan saat persalinan, riwayat konsumsi alkohol dan riwayat abortus tidak terbukti sebagai faktor risiko kejadian BBLR pada penelitian ini.

\section{KONFLIK KEPENTINGAN}

Penulis menyatakan tidak terdapat konflik kepentingan dalam penelitian ini.

\section{ETIKA DALAM PENELITIAN}

Penelitian ini telah mendapat persetujuan dari Komisi Etik Fakultas Kedokteran Universitas Udayana/RSUP Sanglah Denpasar 2113/UN14.2.2.VII.14/LT/2020.

\section{PENDANAAN}

Penelitian ini tidak mendapatkan dana dari pemerintah ataupun sekotor swasta lainnya.

\section{KONTRIBUSI PENULIS}

I Gusti Ngurah Yuda Bagus Aryana bertanggung jawab terhadap pengumpulan data, analisis data, penyusunan naskah penelitian. Komang Ayu Kartika Sari dan Putu Aryani supervise penelitian, analissi data, penuntunan metodelogi.

\section{DAFTAR PUSTAKA}

1. WHO Press. Neonatal and perinatal mortality: country, regional and global estimates. Geneva: WHO. 2014. p. 3-4.

2. Balitbang Kemenkes RI. 2007 Riset Kesehatan Dasar; RISKESDAS. Jakarta: Balitbang Kemenkes RI.

3. Kanda T, Murai-Takeda A, Kawabe H, Itoh $\mathrm{H}$. Low birth weight trends: possible impacts on the prevalences of hypertension and chronic kidney disease. Hypertens Res. 2020;43(9):859868 . 
4. Karima K, Endang LA. Status Gizi Ibu dan Berat Badan Lahir, hal: 111-117. Jakarta: Jurnal Kesehatan Masyarakat. 2012;7(3):19-25.

5. Hailu LD, Kebede DL. Determinants of Low Birth Weight among Deliveries at a Referral Hospital in Northern Ethiopia. BioMed Res Int. 2018;20(3):13-19.

6. Mallia T, Grech A, Hili A, Calleja-Agius J, Pace NP. Genetic determinants of low birth weight. Minerva Ginecol. 2017;69(6):631-643.

7. Basel PL, Singh S. Low birth weight and its associated risk factors: Health facilitybased case-control study. PLoS One. 2020;15(6):e0234907.

8. Hughes MM, Black RE, Katz J. 2500-g Low Birth Weight Cutoff: History and Implications for Future Research and Policy. Matern Child Health J. 2017;21(2):283-289.

9. National Academies of Sciences, Engineering, and Medicine; Health and Medicine Division; Division of Behavioral and Social Sciences and Education; Board on Children, Youth, and Families; Committee on Assessing Health Outcomes by Birth Settings. Birth Settings in America: Outcomes, Quality, Access, and Choice. Backes EP, Scrimshaw SC, editors. Washington (DC): National Academies Press (US); 2020. PMID: 32049472.

10. Cantarutti A, Franchi M, Monzio Compagnoni M, Merlino L, Corrao G. Mother's education and the risk of several neonatal outcomes: an evidence from an Italian populationbased study. BMC Pregnancy Childbirth. 2017;17(1):221-229.

11. Muyunda B, Makasa M, Jacobs C, Musonda P, Michelo C. Higher Educational Attainment Associated with Optimal Antenatal Care Visits among Childbearing Women in Zambia. Front Public Health. 2016;4:127.

12. Casas M, Cordier S, Martínez D, Barros H, Bonde JP, Burdorf A. Maternal occupation during pregnancy, birth weight, and length of gestation: combined analysis of 13 European birth cohorts. Scand J Work Environ Health. 2015;41(4):384-96.
13. Khojasteh F, Arbabisarjou A, Boryri T, Safarzadeh A, Pourkahkhaei M. The Relationship between Maternal Employment Status and Pregnancy Outcomes. Glob J Health Sci. 2016;8(9):55-63.

14. Getaneh T, Negesse A, Dessie G, Desta M. The impact of pregnancy induced hypertension on low birth weight in Ethiopia: systematic review and meta-analysis. Ital J Pediatr. 2020;46(1):174182

15. Kurabayashi $T$, Mizunuma $H$, Kubota $T$, Nagai K, Hayashi K. Low Birth Weight and Prematurity Are Associated with Hypertensive Disorder of Pregnancy in Later Life: A CrossSectional Study in Japan. Am J Perinatol. 2020. doi: 10.1055/s-0040-1705134.

16. Sharma M, Mishra S. Maternal risk factors and consequences of low birth weight in Infants. IOSR Journal of Humanities And Social Science (IOSR-JHSS). 2013;13(4):39-45.

17. Mvunta MH, Mboya IB, Msuya SE, John B, Obure J, Mahande MJ. Incidence and recurrence risk of low birth weight in Northern Tanzania: A registry based study. PLoS ONE. 2019;14(4):1-10.

18. Barros AJ, Santos Ida S, Victora CG, Albernaz EP, Domingues MR, Timm IK, dkk. The 2004 Pelotas birth cohort: methods and description. Rev Saude Publ. 2006;40(3):402-413.

19. Krymko H, Bashiri A, Smolin A, Sheiner E, Bar-David J, Shoham-Vardi I, dkk. Risk factors for recurrent preterm delivery. Eur J Obstet Gynecol Reprod Biol. 2004;113(2):160-163.

20. Sclowitz IKT, Santos I, Domingues MR, Matijasevich A, Barros AJD. Prognostic factors for low birthweight repetition in successive pregnancies: a cohort study. BMC Pregnancy and Childbirth. 2013;13:20-29.

21. Sutan R, Mohtar M, Mahat AN, Tamil AM. Determinant of Low Birth Weight Infants: A Matched Case Control Study. Open Journal of Preventive Medicine. 2014;4(3):91-99.

22. Ouyang F, Zhang J, Betran AP, Yang Z. Recurrence of adverse perinatal outcomes in developing countries. Bull World Health Organ. 2014;91:357-67.
23. Colson NJ, Naug HL, Nikbakht E, Zhang P, McCormack J. The impact of MTHFR $677 \mathrm{C} / \mathrm{T}$ genotypes on folate status markers: a metaanalysis of folic acid intervention studies. European Journal of Nutrition. 2015;56(1):24760.

24. Chen Y, Wu L, Zhang W, Zou L, Li G, Fan L. Delivery modes and pregnancy outcomes of low birth weight infants in China. J Perinatol. 2016;36:41-46.

25. Wu H, Zhu P, Geng X, Liu Z, Cui L. Genetic polymorphism of MTHFR C677T with preterm birth and low birth weight susceptibility: a meta-analysis. Archives of Gynecology and Obstetric. 2017;295(5):1105-18.

26. Figueiredo ACMG, Gomes-Filho IS, Silva RB. Maternal Anemia and Low Birth Weight: A Systematic Review and Meta-Analysis. Nutrients. 2018;10(5):601-610.

27. Rahmati S, Delpishe A, Azami M, Hafezi Ahmadi MR, Sayehmiri K. Maternal Anemia during pregnancy and infant low birth weight: A systematic review and Meta-analysis. Int J Reprod Biomed. 2017;15(3):125-134.

28. Khan A, Nasrullah FD, Jaleel R. Frequency and risk factors of low birth weight in term pregnancy. Pak J Med Sci. 2016;32(1):138-142.

29. Pereira PP, Da Mata FA, Figueiredo AC, de Andrade KR, Pereira MG. Maternal Active Smoking During Pregnancy and Low Birth Weight in the Americas: A Systematic Review and Meta-analysis. Nicotine Tob Res. 2017;19(5):497-505.

30. Pereira PPDS, Mata FAFD, Figueiredo ACMG, Silva RB, Pereira MG. Maternal Exposure to Alcohol and Low Birthweight: A Systematic Review and Meta-Analysis. Rev Bras Ginecol Obstet. 2019;41(5):333-347.

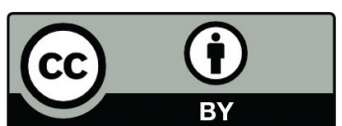

This work is licensed under a Creative Commons Attribution 